\title{
Local Community Involvement and Quality of Life in Tourism Destination Development: Case of Coastal Tourism in West Java, Indonesia
}

\author{
Fitri Abdillah
}

\author{
Sekolah Tinggi Pariwisata Bali Internasional, Bali, Indonesia \\ Corresponding author: fitri adie@yahoo.com
}

\begin{abstract}
ARTICLE INFO
ABSTRACT

Received

20 March 2016

Accepted

30 August 2016

Available online 15 September 2016

The community in the tourism destination is one of the key elements to ensure the sustainability of the tourism destination itself. The objective of this study was to determine if the development of tourism contributes to the involvement and the level of quality of life of the local community in Pangandaran and Palabuhanratu. A total of 279 samples were obtained from two locations. Data were analyzed by using descriptive methods to determine the phase of the development of destinations, the community involvement, and the level of quality of life The results showed that (1) Pangandaran has a better destination performance than Palabuhanratu, (2) Pangandaran is in the growth phase and Palabuhanratu is in the consolidation phase, (3) Increase in the number of tourist arrivals in destinations within the growth phase is more influential than that in the consolidation phase, and (4) Among the four components of quality of life, the material aspect has the highest value, followed by the spiritual, social and personal aspects. The development of tourism destinations significantly affected the level of community involvement and the level of quality of life.
\end{abstract}

Keywords: development, involvement, quality of life

\section{Introduction}

The implication of the development of tourism destinations is a multiplier impact for the community in the tourism destinations. Inskeep (1991) stated that the development of tourism destinations will be successful if it is able to improve the welfare of the people around the development zone. Community is one of the important components and its involvements help determine the development of a tourism destination. The community's involvements have resulted in the changes in their lives as a result of interaction with tourists. In some research, this welfare is often defined as the quality of life (Kim, 2002). The general and macro measurement often used to measure the quality of life is the Human Development Index (HDI). The data show that the provinces in Indonesia known as the province of tourism have a lower HDI value compared to the average of the national index. This means that in general, tourism has not been optimally supported the improvement of quality of life. However, is it true that tourism does not contribute to improving the quality of life?

In addition to the general and macro measurement above, the level of the quality of life can also be measured by the satisfaction on physical needs, social environment, and other necessities of life. Research of Kim (2002) concluded that the development of tourism has a positive impact on improving the material, social, and emotional well-being. Tourist arrivals results in the increased material well-being that makes the people more prosperous socially and emotionally. Therefore Benckendorff et al. (2009) stated that the relationship between the development 
of tourism destinations and the quality of life is still being debated. Thus, tourism is assumed to affect the lives of people's satisfaction. Therefore, this study was designed to analyze the contribution of the development of tourism destinations to the level of the quality of life of the local people.

In the context of the development of tourism destinations in Indonesia, the West Java Province occupies a strategic position. The tourism performance in West Java has been greatly supported by the abundant number of tourists from the capital city of Jakarta. Nonetheless, West Java has contributed only approximately $10 \%$ of the performance of national tourism, yet this region has various attractive tourism destinations to visit, including the Pangandaran and Palabuhanratu. The objective of the research was to find out if in micro economics, the development of tourism can contribute to the involvement and the quality of life of the local people in Pangandaran and Palabuhanratu.

As a dynamic system, tourism is the interaction of various components including the local people as a part of it. This interaction has positive and negative consequences. Diedrich and García-Buades (2009) stated that there is a strong correlation between the public perception on the impact of tourism development and the stage of development of tourism destination itself. In the early stages of tourism development shown that the local people tend to have a positive attitude, but after massive development, their perceptions will turn into negative.

The people's positive behavior towards tourism is related to how the local people enjoy their lives in the community (Jurowski and Brown, 2001). Therefore, this study focused on the inter-relationship between the development of tourism destinations, the involvement and the quality of life of the local people in it. Some theories underlying these notions are as follows.

a) Stage of development of tourism destinations refers to the model developed by Butler (1980); destination will evolve according to a cyclical model starting from the absence of tourism activities, until the massive development in the form of mass exploitation and subsequently saturation and decline occur.

b) The level of the local people's involvement in development is defined as community participation in the development activities, which are divided into: planning, implementation, and monitoring. Community involvement is measured by using the ranking system of Arnstein (1969) with three levels, namely non-participation, tokenism, and independence.

c) Quality of life is defined as individual satisfaction of all dimensions of life. Quality of life of the local communities is measured subjectively and grouped into four aspects, including aspects of material life (Kim, 2002), aspects of social life (Norman, Harwell and Allen, 1997), aspects of personal life (Sirgy, 2001), and aspects of spiritual life (Paloutzian and Ellison, 1982).

\section{Research Objective:}

The objective of this study was to determine if the development of tourism contributes to the involvement and the level of quality of life of the local community in Pangandaran and Palabuhanratu.

\section{Methodology}

The study analyzed the interrelation between the development of tourism destinations, the involvement of local communities, and the quality of life. The development of tourism destinations was measured by the fluctuation of data on the five attributes of tourism destinations, namely tourists, accommodations, attractions, accessibility and amenities. Community involvement is measured by the ranking system of participation that includes three development stages: planning, implementation, and monitoring. The quality of life was measured by the individuals' subjective perception of the community about their satisfaction with the four aspects of quality of life i.e. the material, the social, the personal, and the spiritual aspects. The pattern of interrelation of these three development stages are described as follows. 


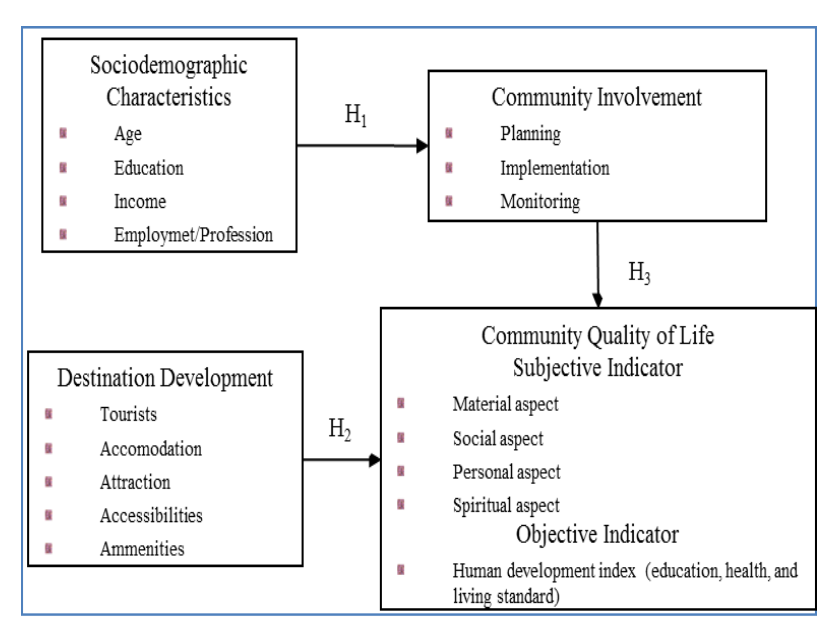

Figure 1 Framework of Thinking

The research method is survey research by combining qualitative and quantitative approaches. The research was conducted in the Pananjung Village of Pangandaran and Citepus Village of Palabuhanratu. Samples were the local people of the two villages. Samples were taken using purposive method with minimum criteria of 100 samples for each village. A total of 279 samples were obtained from both locations. Data were analyzed by descriptive methods to determine the rate of development of tourism destinations, the community involvement and the quality of life. The index rate of development of tourism destinations was used to plot the development of tourism destinations based on the model of Butler (1980). The community involvement was known from the respondents' answers on the statement of participation and it was plotted in the Arnstein's participation ladder (1969). The quality of life of the local people was found out by make up the quality of life index which consists of the material aspects, the social aspects, the personal aspects, and the spiritual aspects. Comparative analysis was conducted to find differences in the character of the development of destination, the community involvement, and the quality of life in Pangandaran and Palabuhan ratu.

\section{Results and Discussion}

\section{Tourism Destination Development}

The discussion on the development of tourism destinations is a discussion of the attributes of tourism destinations. Among the various researchers, it seems that the approaches of Buhalis (2000) and Inskeep (1991) are easier to be implemented in Pangandaran and Palabuhanratu, compared with attributes proposed by other researchers. The approaches stated that tourist destinations have tourism determinants in the forms of tourists, tourist attractions, accessibility, amenities and accommodations.

The data showed that the number of tourists visiting Palabuhanratu was higher compared to Pangandaran. In both areas, it was gained the same impression about the season of tourists who utilize national holidays and weekends to visit. In the days of national holidays, there was a surge in the number of tourists that exceeded the capacity of locations in both regions, so that traffic congestion cannot be avoided. It is then taken up by the people with a variety of simple service activities such as foodstalls and rest area, resulting in a profitable symbiosis. The development of accommodation in both regions showed a different pattern. Although the data showed that the number of tourists to Pangandaran was smaller compared to Palabuhanratu, investments for the construction of accommodation are more taking place in Pangandaran. It can be seen from the increasing number of non-star hotels and homestays. This development is due to its greater distance and the number of attractions that must be visited in Pangandaran made travelers should spend the night in Pangandaran. Tourists prefer to stay at nonstar hotels and homestays available. Therefore, businesses of non-star hotels and homestays are more desirable in Pangandaran.

The considerable increase of the number of tourists in the region did not lead to the improvement of infrastructure. This seems to be related to the local government policies that have not been in favor of tourism, although admittedly tourism has an important role in the development. The development of amenities in Palabuhanratu seems to thrive better than that in Pangandaran. The development of amenities of both economic and non-economic was assumed to be related to the development of Palabuhanratu as the district capital and the economic center in the southern part of the area of Sukabumi. 
In general, Pangandaran has higher index of quality than Palabuhanratu. Based on the characteristics of tourism destinations, Pangandaran and Palabuhanratu can be plotted into Butler (1980) curve and illustrated in the Figure 2.

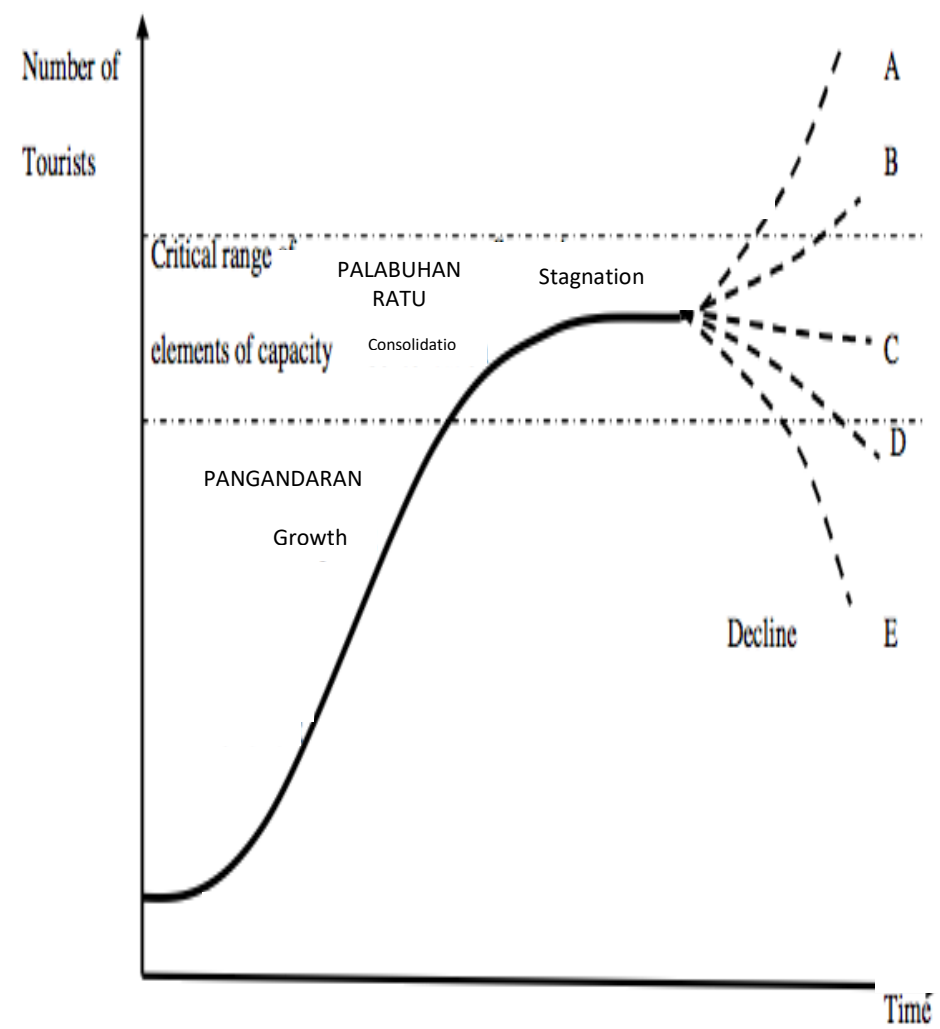

Figure 2 Illustrative Mapping of Pangandaran and Palabuhanratu in Butler Curve (1980)

The figure of illustration above shows that Pangandaran is in the growth phase and Palabuhanratu is in the consolidation phase. According to Butler (1980) tourism destination in the growth phase is marked by the rise of investments mainly accommodation as well as the emergence of new tourist attractions in accordance with the needs of visitors. Public facilities have been changed into business premises. Investments that mainly for business accommodation are on the increase both by investors and the local community itself. Thus, the growth phase means that development should always be done to keep improving the quality of destinations in order to remain sustainable.
Applications of Butler (1980) showed that the study supports the model. The purpose of applying this model is to estimate the position of the development of tourism destinations. This seems to correspond with the opinion of da Conceição Gonçalves and Águas (1997) which stated that for the sake of development decision-making, the implementation of the model can be conducted. With this standard foundation, it can be concluded that a particular phase has characteristics of specific involvement and quality of life as well.

The conclusion from the above discussion is that the tourism destination which is in the growth phase, the development of the number of tourist has led to more multiplier effect of increased business accommodation, tourist attractions and informal community businesses, compared to that of tourism destination which is in the consolidation phase. Tourist developments in the two phases are not significantly led to the development of infrastructure. The development of the infrastructure development supported by government programs that are meant not only for the purpose of development of tourism destinations alone.

\section{Local Community Involvement}

The results showed that community involvement in the planning stages is in nonparticipation level. Low levels of community involvement in planning is thought to be caused by the way of the planning approach which does not foster participation. This is in accordance with the opinion of Guzman, (1989 cited by Sunarti, 2008) which states that the failure of the people involved in the development is caused by (1) less strategies in fostering community engagement that should be part of the development program, (2) the community is considered as people who do not understand about the development plans. Low education levels and lack of ability to identify the problems that became the basis of these assumptions, and (3) the existing organizations or local institutions are often managed by nonparticipatory mechanism, but is used as a legalization program that has already been planned. 
In the implementation phase, the involvement is ranked independence. This happens because the actual implementation phase occurs during the interaction between the local people and the tourists. The people seek to benefit from the arrival of tourists, with an initiative to set up profitable businesses. However, these initiatives are often not in accordance with the rules and regulations set by the government. This community initiative was realized with the risk that if the government making the arrangement of the locations, then they are ready to be relocated. This fact is consistent with the findings of Cooper (1995) that the development of tourism destinations are always characterized by fragmentation and domination by retail businesses whose existence following the tourist season. The domination of the retail businesses can be seen by the development of the food stalls, especially in Pangandaran with the amount exceeding 20 percent per year.

At the monitoring stage, the community involvement is ranked tokenism. Communities take the monitoring initiative in the form of daily interaction between community members as well as interaction with the tourists. The government play a role as a regulator generally relates to the structuring of zoning, licenses/permits and taxes or levies. However, monitoring by both the public and the government seemed as oversight hesitation. As if the government ignored for the sake of tax considerations in order to increase the local revenues (PAD). Thus, continuous monitoring is not conducted, the lack of enforcement of clear rules, and only performed with the orientation of regional income. This is the reason for the lower public participation in the planning stage, while at the operational stage, the role of government is very strong and declining at the monitoring stage. The pattern of community involvement in the two regions can be described by the ranking ladder of Arnstein (1969) in Table 1.
Table 1.

The pattern of community involvement in the two regions by the ranking ladder

\begin{tabular}{|c|c|c|c|c|c|c|}
\hline \multirow{3}{*}{$\begin{array}{c}\text { Particip } \\
\text { ation } \\
\text { ladder } \\
\text { Arnstei } \\
\mathrm{n} \\
(1969)\end{array}$} & \multicolumn{6}{|c|}{ Stage } \\
\hline & \multicolumn{2}{|c|}{ Planning } & \multicolumn{2}{|c|}{$\underset{n}{\text { Implementatio }}$} & \multicolumn{2}{|c|}{ Monitoring } \\
\hline & $\begin{array}{c}\text { Pang } \\
\text { andar } \\
\text { an }\end{array}$ & $\begin{array}{c}\text { Palab } \\
\text { uhanr } \\
\text { atu }\end{array}$ & $\begin{array}{l}\text { Pang } \\
\text { andar } \\
\text { an }\end{array}$ & $\begin{array}{c}\text { Palab } \\
\text { uhanr } \\
\text { atu }\end{array}$ & $\begin{array}{c}\text { Pang } \\
\text { andar } \\
\text { an }\end{array}$ & $\begin{array}{c}\text { Palab } \\
\text { uhanr } \\
\text { atu }\end{array}$ \\
\hline \multirow{2}{*}{$\begin{array}{l}\text { Nonpar } \\
\text { ticipati } \\
\text { on }\end{array}$} & & & & & & \\
\hline & $\begin{array}{c}74,1 \\
\%\end{array}$ & $\begin{array}{c}91,2 \\
\%\end{array}$ & & & & \\
\hline
\end{tabular}

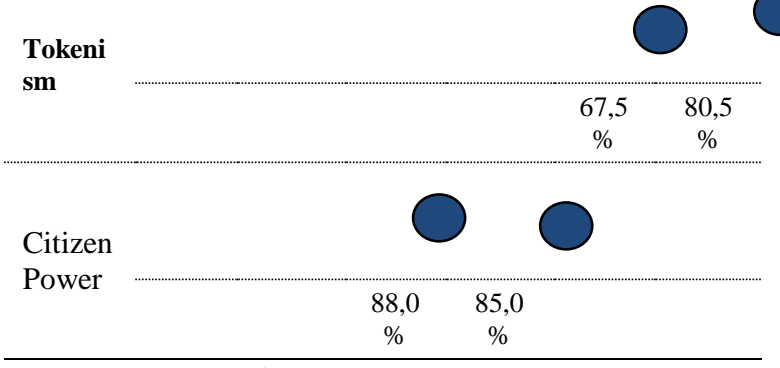

Resouces: Primary Data (2014)

From the table it can be seen that in the two regions showed the same pattern of community involvement. The involvement of non-participation in the planning, independent involvement in the implementation, and involvement of tokenism in the monitoring. Such a pattern is a common pattern in development planning in Indonesia. According to Rosyida and Nasdian (2011) the concept of technocratic planning still dominates the development planning in Indonesia. The implications of minimum community involvement in planning is the euphoria of involvement in the implementation phase, especially during the high tourist seasons.

The study's findings also indicated that the difference in the profession affected on the community involvement in Pangandaran and Palabuhanratu. It seems that the attractiveness of the jobs has made the local people interested in getting involved, especially in the implementation of the development. Of the various types of professions, it was mostly entrepreneurs. The types of business are mostly traders either foods or grocery stores. It is the professions that encourage people to get involved instead of education, age and income. It is believed to be related to the perception that jobs will 
generate revenue, and jobs can be used as a medium for socializing. A good job can encourage someone to get involved in community activities. Usually people with certain job levels will be able to spend or not even take the slightest time to engage in certain activities.

The conclusion of this discussion is that in the phase of the development of tourism destinations has not resulted in changes in the rating of involvement of the ladder of in participation, but in the destination with the growth phase, the pattern of community involvement in the planning, implementation, and monitoring tended to be more moderate. In the consolidation phase tended to be more extreme at the planning stage, the public would probably not get involved, but at the implementation stage more number of people involved. These patterns describe how decisions are made by the community. Involvement also influenced by other people's activities, particularly the jobs. The desire to do the same things as others, seems to be more dominant in the community in tourism destinations during the consolidation phase.

\section{Local Community Quality of Life}

Aggregately, the quality of life index of Pangandaran was better than the Palabuhanratu. This finding also confirms the opinion of Inskeep (1991) and Jurowski (1994) about the importance of community in the development of tourism. The good performance of destination development will be marked with the good level of quality of life as well. The aggregate value of quality of life index is presented in the following table.

Tabel 1

Local Community Quality of Life Pangandaran and Palabuhanratu

\begin{tabular}{lccccc}
\hline \multirow{2}{*}{ No Aspect } & \multicolumn{2}{c}{ Arithmetic Weight Mean } & \multicolumn{2}{c}{ Index } \\
\cline { 2 - 5 } & & \\
& Pangandaran Palabuhanratu Pangandaran Palabuhanratu \\
\hline I $\quad$ Material & 71,77 & 70,46 & 21,53 & 21,14 \\
\hdashline II Social & 68,73 & 69,56 & 17,18 & 17,39 \\
\hline III Personal & 72,39 & 72,09 & 18,10 & 18,02 \\
\hline IV Spiritual & 79,06 & 77,88 & 15,81 & 15,58 \\
\hline Quality of Life Index & & 72,63 & 72,12 \\
\hline
\end{tabular}

Resouces: Primary Data (2014)
The above table shows that in terms of material aspects, Pangandaran has a higher index than Palabuhanratu. It can be seen from the components that forming the material aspect. It is known that all components in the material aspects of Pangandaran showed a higher value than Palabuhanratu. Two things that are assumed to be the causes: the social character of the community and the people's work ethic. The social character of fishermen has a more open character. Uncertainty factor which was higher than in agriculture led to the fishing communities had to work harder to get adequate results. This pattern is shaping the community work ethic of Pangandaran to be higher than that in Palabuhanratu.

The analysis showed that there was a weak and significant correlation between the community involvement and the quality of life. This value indicates that the involvement of the community turned out to contribute to the level of quality of life of local communities $\left(\mathrm{r}_{\mathrm{png}}=0.219\right.$ dan $\left.\mathrm{r}_{\mathrm{plb}}=0.270\right)$. The relationship was so significant that it cannot be ignored. Accordingly, aspects of the development of tourism destinations and community involvement affected the quality of life of the local communities. The weak correlation value was assumed to be caused by the level of quality of life which was measured subjectively using the micro-scale of individual communities.

The conclusion obtained that the involvements of the local communities in both locations were determined in tourism activities. This finding is consistent with the research conducted by (Jurowski, 1994; Andereck and Vogt, 2000) which states that the level of the local quality of life is determined by the activity of tourism as a tool to improve the economic position. Their hope is to obtain a better job, while maintaining the socio-cultural and environmental conditions. Thus, the development of tourism destinations can create social justice and provide economic security through its involvement in the development. 


\section{Tourism Destination Development, Local Community Involvement and Quality of Life}

Based on description above, the relationship between the development of tourism destinations and community involvement, and quality of life can be generalized by assessing the the relationship of all three. The data in Table 3 illustrates the relationship between the development of destinations, the community involvement and the quality of life. In terms of destination development, the performance of Pangandaran was better than that of Palabuhanratu. Better development was supported by a rating factor, where tourists have a longer stay so as to spend more money. The factor of length of stay was supported by the facst of selection of objects and tourist attractions in Pangandaran are more varied than the Palabuhanratu. The decisions of tourists to stay longer also due to the provision of better accommodation facilities and access. This suggests that the development of destinations from Pangandaran was better than Palabuhanratu.

Tabel 2

Interrelation among Destination Development, Local Community Involvement and Quality of Life

\begin{tabular}{|c|c|c|c|}
\hline \multirow[b]{2}{*}{ Item analyse } & \multicolumn{2}{|c|}{ Destinations } & \multirow{2}{*}{$\begin{array}{c}\text { Comparati } \\
\text { ve } \\
\text { Analysis }\end{array}$} \\
\hline & $\begin{array}{l}\text { Pangandaran } \\
\text { (A) }\end{array}$ & $\begin{array}{c}\text { Palabuhanrat } \\
\text { u (B) }\end{array}$ & \\
\hline \multicolumn{4}{|c|}{ Destination Development } \\
\hline $\begin{array}{l}\text { Growth of } \\
\text { number of } \\
\text { tourist }\end{array}$ & 0,300 & 0,270 & $\mathrm{~A}>\mathrm{B}$ \\
\hline $\begin{array}{l}\text { Growth of } \\
\text { number of } \\
\text { accomodati } \\
\text { on }\end{array}$ & 0,225 & 0,138 & $\mathrm{~A}>\mathrm{B}$ \\
\hline $\begin{array}{l}\text { Growth of } \\
\text { number of } \\
\text { object and } \\
\text { attraction }\end{array}$ & 0,125 & 0,050 & $\mathrm{~A}>\mathrm{B}$ \\
\hline $\begin{array}{l}\text { Growth of } \\
\text { number of } \\
\text { accesibility }\end{array}$ & 0,125 & 0,101 & $\mathrm{~A}>\mathrm{B}$ \\
\hline $\begin{array}{l}\text { Growth of } \\
\text { number of } \\
\text { amenity }\end{array}$ & 0,075 & 0,150 & $\mathrm{~A}<\mathrm{B}$ \\
\hline $\begin{array}{l}\text { Destination } \\
\text { developmen } \\
\mathrm{t} \text { phase }\end{array}$ & $\begin{array}{c}0,845 \\
\text { (Developmen } \\
\text { t) }\end{array}$ & $\begin{array}{c}0,709 \\
\text { (Consolidatio } \\
\mathrm{n})\end{array}$ & $\mathrm{A}>\mathrm{B}$ \\
\hline \multicolumn{4}{|c|}{ Local Commnity Involvement } \\
\hline Planning & $\begin{array}{c}\text { Nonparticipat } \\
\text { ion }\end{array}$ & $\begin{array}{l}\text { Nonparticipat } \\
\text { ion }\end{array}$ & $\mathrm{A}=\mathrm{B}$ \\
\hline
\end{tabular}

http://ojs.unud.ac.id/index.php/eot

\begin{tabular}{|c|c|c|c|c|}
\hline 国 & $\begin{array}{l}\text { Implementa } \\
\text { tion }\end{array}$ & $\begin{array}{l}\text { Citizen } \\
\text { power }\end{array}$ & $\begin{array}{l}\text { Citizen } \\
\text { power }\end{array}$ & $A=B$ \\
\hline 紧 & Monitoring & Tokenism & Tokenism & $\mathrm{A}=\mathrm{B}$ \\
\hline \multicolumn{5}{|c|}{ Local Community Involvement } \\
\hline (a) & $\begin{array}{l}\text { Material } \\
\text { aspect index }\end{array}$ & 21,53 & 21,14 & $A>B$ \\
\hline 要 & $\begin{array}{l}\text { Community } \\
\text { aspect index }\end{array}$ & 17,18 & 17,39 & $\mathrm{~A}<\mathrm{B}$ \\
\hline 国 & $\begin{array}{l}\text { Personal } \\
\text { aspect index }\end{array}$ & 18,10 & 18,02 & $A>B$ \\
\hline 国 & $\begin{array}{l}\text { Spiritual } \\
\text { aspect index }\end{array}$ & 15,81 & 15,58 & $A>B$ \\
\hline (a) & $\begin{array}{l}\text { Total } \\
\text { aspect index }\end{array}$ & 72,63 & 72,12 & $A>B$ \\
\hline \multicolumn{5}{|c|}{$\begin{array}{l}\text { Correlation between Community Involvement and Quality of } \\
\text { Life }\end{array}$} \\
\hline : & $\begin{array}{l}\text { Material } \\
\text { aspect }\end{array}$ & $0,234^{* *}$ & $0,165^{*}$ & $\mathrm{~A}>\mathrm{B}$ \\
\hline 四 & $\begin{array}{l}\text { Community } \\
\text { aspect }\end{array}$ & $0,173^{*}$ & 0,111 & $A>B$ \\
\hline 娄 & $\begin{array}{l}\text { Personal } \\
\text { aspect }\end{array}$ & 0,078 & 0,156 & $A>B$ \\
\hline 圆 & $\begin{array}{l}\text { Spiritual } \\
\text { aspect }\end{array}$ & $0,232 * *$ & $0,304 * *$ & $\mathrm{~A}<\mathrm{B}$ \\
\hline & $\begin{array}{l}\text { Noted } \\
\text { at the } 0.05\end{array}$ & \multicolumn{3}{|c|}{$\begin{array}{l}: * \text {. Correlation is significant } \\
\text { vel (1-tailed). } \\
* * \text {. Correlation is significant } \\
\text { e } 0.01 \text { level (1-tailed). }\end{array}$} \\
\hline
\end{tabular}

It can be seen that the development phase and the involvement of the local communities affected the quality of life of the local communities in the material, social, and spiritual aspects. Thus, the people involved in tourism development with the purpose to increase the prosperity in terms of economic, social relation, and spiritual values. In the consolidation phase, the involvement of the local communities is affecting the quality of life in terms of material aspect, and spiritual aspect. The local communities were interested to be involved in the destination development in order to increase the prosperity in the economic sense, and spiritual values.

The interesting finding of this research was that the increasing number of domestic tourists in Pangandaran has no significant effect on the quality of life in the community. It is believed to be related to the degree of heterogeneity in Pangandaran. This heterogeneity level causes a more flexible attitude towards immigrants and their impacts on quality of life in community are smaller. 
Some heterogeneous characters stated by Britha (1999) namely: similarity, equality, democracy, solidarity, justice and social solidarity. These principles seem to be going well in Pangandaran so that the revenues from domestic tourists do not cause changes in the overall quality of life.

However, the findings strengthen the opinion of Benckendorff et al. (2009) that research on the quality of life of the local people, put more emphasis on how the impact of tourism development can affect their life satisfaction. The study's findings also support the notion of Liu and Var (1986) that people realize that tourism can have a positive impact on the economy but are reluctant to accept changes in environmental and social aspects due to tourism. Thus the developments of tourism destinations in both study areas, were not fully lead to positive changes in all aspects of quality of life there.

Based on the above discussion some points can be synthesized as follows.

First, Pangandaran has a better performance compared to Palabuhanratu. Pangandaran is in the growth phase and Palabuhanratu is in the consolidation phase when plotted in the model of TALC of Butler (1980). The study's findings do not completely follow that model, because the use of the attributes of the tourism destination corrected the development phase of destination is not only determined by the growing number of tourists.

Second, the pattern of community involvement in the two phases of the development of tourism destinations show a similar pattern. Tourism destination development phase did not cause a change in the ranking of the ladder of participation, but at the destination with the growth phase, the pattern of community involvement in the planning, implementation, and monitoring tend to be more moderate.

http://ojs.unud.ac.id/index.php/eot
Third, the level of quality of life of the local communities in both destinations showed a high level. Among the four aspects of quality of life, the material aspect is in the highest position, followed by the spiritual aspect, the social aspect and the personal aspect.

Fourth, there was a positive relationship between the community involvements with the quality of life of society as a whole. Thus, the developments of tourism destinations have an impact on the level of community involvement and the quality of life. The value of influence was weak but could not be ignored. Such findings indicate that research carried out by Kim (2002), about the positive impact of tourism development on improving the material, social, and emotional well-beings, and Jurowski (1994) about the positive impact of tourism development on the quality of life, does not seem entirely correspond with the situation in the two areas.

\section{Conclusion}

The development of tourism destinations significantly affected the level of community involvement and the level of quality of life, Pangandaran has a better destination performance than Palabuhanratu, Pangandaran is in the growth phase and Palabuhanratu is in the consolidation phase, Increase in the number of tourist arrivals in destinations within the growth phase is more influential than that in the consolidation phase, and among the four components of quality of life, the material aspect has the highest value, followed by the spiritual, social and personal aspects.

\section{Recommendation}

First, the development of tourism destinations is defined as an increase in the number of tourists which increased attributes of other destinations. Therefore, the government with tourism stakeholders need to make good planning and strategic steps to ensure that the growth of the number of tourists result in the positive impact on improving the quality of attributes of tourism 
destinations. Second, the facts show that the higher the involvement of the community, the better the performance of tourism destinations. Therefore, to improve the performance of the tourism destination, it is required a higher community involvement. The pattern of community involvement needs to be shifted from passive to active pattern. Third, the facts that the development of tourism destinations significantly influenced on the level of quality of life of the local communities. The significant positive effect was shown in the material and spiritual aspects of quality of life, while the social and personal aspects showed the opposite pattern. Therefore, it is necessary for efforts to protect the assets of society against loss due to the development of tourism. Strengthening the social institutions and communication between stakeholders should continue to be developed.

\section{References}

Andereck, K. L. and Vogt, C. A. (2000) 'The relationship between residents' attitudes toward tourism and tourism development options', Journal of Travel research. Sage Publications Sage CA: Thousand Oaks, CA, 39(1), pp. 27-36.

Benckendorff, P., Edwards, D., Jurowski, C., Liburd, J. J., Miller, G. and Moscardo, G. (2009) 'Exploring the future of tourism and quality of life', Tourism and Hospitality Research. Sage Publications, 9(2), pp. 171-183.

Britha, M. (1999) 'Metode Penelitian Partisipatori dan Upaya-Upaya Pemberdayaan: Sebuah Buku Pegangan bagi Praktisi Lapangan', Yayasan Obor Indonesia. Jakarta, 438.
Buhalis, D. (2000) 'Marketing the competitive destination of the future', Tourism management. Elsevier, 21(1), pp. 97-116.

Butler, R. W. (1980) 'The concept of a tourist area cycle of evolution: implications for management of resources', The Canadian Geographer/Le Géographe canadien. Wiley Online Library, 24(1), pp. 5-12.

da Conceição Gonçalves, V. F. and Águas, P. M. R. (1997) 'The concept of life cycle: an application to the tourist product', Journal of Travel Research. SAGE Publications Sage CA: Los Angeles, CA, 36(2), pp. $12-22$.

Cooper, C. (1995) 'Strategic planning for sustainable tourism: the case of the offshore islands of the UK', Journal of sustainable tourism. Taylor \& Francis, 3(4), pp. 191209.

Diedrich, A. and García-Buades, E. (2009) 'Local perceptions of tourism as indicators of destination decline', Tourism Management. Elsevier, 30(4), pp. 512-521.

Guzman, P. (1989) People Participation a Stimulus for Effecting and Sustaining Improvement in Farmer Communities. 22nd Regional Training DSPFC. Laguna: SEARCA.

Inskeep, E. (1991) Tourism planning: an integrated and sustainable development approach. Van Nostrand Reinhold. 
Jurowski, C. (1994) 'The interplay of elements affecting host community resident attitudes toward tourism: A path analytic approach (Doctoral Dissertation)', Virginia Polytechnic Institute and State University, Blacksburg, Virginia.

Jurowski, C. and Brown, D. O. (2001) 'A comparison of the views of involved versus noninvolved citizens on quality of life and tourism development issues', Journal of Hospitality \& Tourism Research. Sage Publications Sage CA: Thousand Oaks, CA, 25(4), pp. 355-370.

Kim, K. (2002) 'The effects of tourism impacts upon quality of life of residents in the community'. Virginia Polytechnic Institute and State University.

Liu, J. C. and Var, T. (1986) 'Resident attitudes toward tourism impacts in Hawaii', Annals of tourism research. Elsevier, 13(2), pp. 193214.

Norman, W. C., Harwell, R. and Allen, L. R. (1997) 'The role of recreation on the quality of life of residents in rural communities in South Carolina', Developments in quality-of-life studies, 1, p. 65.

Paloutzian, R. F. and Ellison, C. W. (1982) 'Loneliness, spiritual well-being and the quality of life In Peplau LA \& Perlman D.(Eds.), Loneliness: A sourcebook of current theory, research and therapy (pp. 224237)'. New York, NY: Wiley.

Sirgy, M. J. (2001) Handbook of qualityof-life research: An ethical marketing perspective. Springer Science \& Business Media.
Sunarti, E. (2008) 'Partisipasi Masyarakat Dalam Pembangunan Masyarakat', Bogor: IPB. 